Document downloaded from:

http://hdl.handle.net/10251/45180

This paper must be cited as:

Klove, B.; Ala-Aho, P.; Bertrand, G.; Gurdak, JJ.; Kupfersberger, H.; Kvœrner, J.; Muotka, T.... (2014). Climate Change Impacts on Groundwater and Dependent Ecosystems - in press. Journal of Hydrology. 518(Part B):250-266. doi:10.1016/j.jhydrol.2013.06.037.

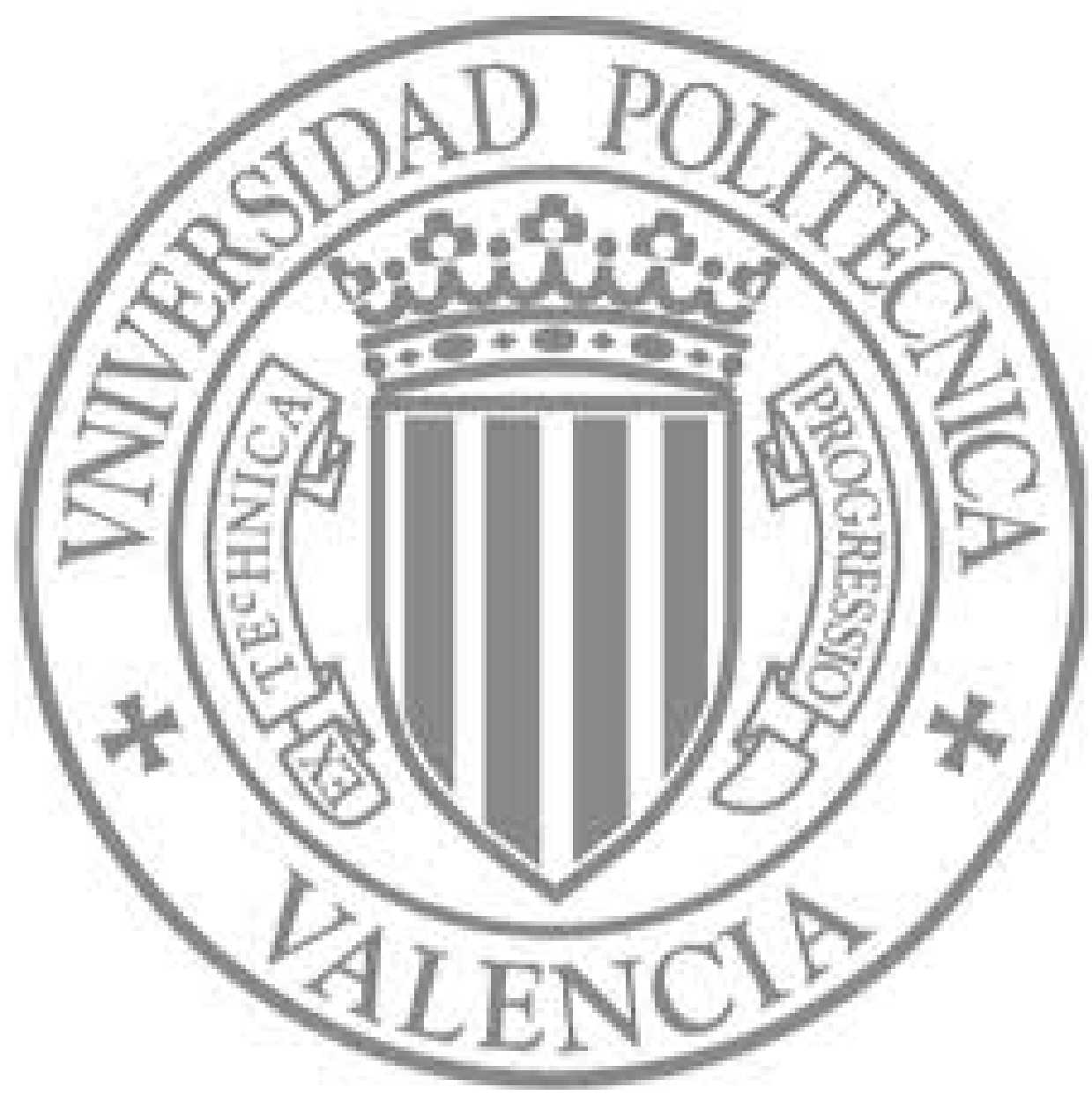

The final publication is available at

http://dx.doi.org/10.1016/j.jhydrol.2013.06.037

Copyright Elsevier 


\section{Climate Change Impacts on Groundwater and Dependent Ecosystems}

2 Bjørn Kløve ${ }^{1,2^{*}}$,Pertti Ala-Aho ${ }^{1}$, Guillaume Bertrand ${ }^{3}$, Jason J. Gurdak ${ }^{4}$, Hans Kupfersberger ${ }^{5}$, 3 Jens Kvœrner ${ }^{2}$, Timo Muotka ${ }^{1}$, Heikki Mykrä ${ }^{1}$, Elena Preda ${ }^{6}$, Pekka Rossi ${ }^{1}$,Cintia Bertacchi

$4 \quad$ Uvo $^{7}$, Elzie Velasco ${ }^{4}$, Manuel Pulido-Velázquez ${ }^{8}$

5

$6 \quad{ }^{1}$ University of Oulu, 90014 University of Oulu, Finland - tel. +358405944514 -fax 3588553

74507 - bjorn.klove@oulu.fi

$8{ }^{2}$ Bioforsk - Norwegian Institute for Agricultural and Environmental Research, Frederik A.

9 Dahls vei 20, N-1432 Ås, Norway - jens.kvarner@ bioforsk.no

$10{ }^{3}$ University of Neuchâtel, Rue Emile-Argand 11 - CP 158 CH - 2009 Neuchâtel, Switzerland -

11 guillaume.bertrand@email.com

$12{ }^{4}$ Department of Geosciences, San Francisco State University, 1600 Holloway Avenue, San 13 Francisco, CA 94132, U.S.A.

$14{ }^{5}$ Joanneum Research Forschungsgesellschaft mbH. Elisabethsr. 16/II, A- 8010 Graz, Austria 15 hans.kupfersberger@joanneum.at

$16{ }^{6}$ University of Bucharest - Splaiul Independentei 91-95, 050095 Bucharest, Romania

$17{ }^{7}$ Water Resources Engineering, Lund University Box 118, 22100 Lund, Sweden

$18{ }^{8}$ Research Institute of Water and Environmental Engineering, Universitat Politècnica de 19 València, Cami de Vera s/n, 46022 Valencia, Spain

20

$21 *$ Corresponding author

22 Bjørn Kløve, University of Oulu, 90014 University of Oulu, Finland - tel. +358 405944514 23 fax 35885534507 - bjorn.klove@oulu.fi

24

Keywords: groundwater, climate, ecosystems, global change, land use, management. 


\section{Abstract}

27 Aquifers and groundwater-dependent ecosystems (GDE) are facing increasing pressure from water consumption, irrigation and climate change. These pressures modify groundwater levels and their temporal patterns and threaten vital ecosystem services such as arable land irrigation and ecosystem water requirements, especially during droughts. This review examines climate

31 change effects on groundwater and dependent ecosystems. The mechanisms affecting natural 32 variability in the global climate and the consequences of climate and land use changes due to anthropogenic influences are summarised based on studies from different hydrogeological strata and climate zones. The impacts on ecosystems are discussed based on current findings on

35 factors influencing the biodiversity and functioning of aquatic and terrestrial ecosystems. The 36 influence of changes to groundwater on GDE biodiversity and future threats posed by climate 37 change is reviewed, using information mainly from surface water studies and knowledge of 38 aquifer and groundwater ecosystems. Several gaps in research are identified. Due to lack of understanding of several key processes, the uncertainty associated with management techniques such as numerical modelling is high. The possibilities and roles of new methodologies such as

41 indicators and modelling methods are discussed in the context of integrated groundwater

42 resources management. Examples are provided of management impacts on groundwater, with 43 recommendations on sustainable management of groundwater.

\section{Introduction}

46 Groundwater is the major freshwater store acting in the hydrological cycle. It provides water for

47 human consumption, agriculture, industry and many groundwater-dependent ecosystems, 48 especially during droughts. In recent decades the increasing use of groundwater for human 
49 consumption and irrigation has resulted in groundwater lowering in large parts of the world

50 (Wada et al., 2010; Treidel et al., 2012). It is well recognised that regional depletion of

51 groundwater resources is a global-scale problem (Konikow and Kendy, 2005). Many

52 groundwater resources are non-renewable on meaningful time scales for both human society

53 and ecosystems. The predicted climate change will exacerbate these concerns in many parts of

54 the world by reducing precipitation and increasing evapotranspiration, both of which will

55 reduce recharge and possibly increase groundwater withdrawal rates (Treidel et al., 2012).

56 Thus, increasing awareness of the importance of wetlands and other groundwater-dependent

57 ecosystems (GDE) has led to emphasis being placed on a better understanding of groundwater-

58 ecosystem interactions in a changing climate (Kløve et al., 2011a, 2011b).

59 While the impacts of groundwater withdrawal and land use on groundwater have been 60 investigated in numerous studies, climate change impacts on groundwater and dependent 61 ecosystems have received less attention (Taylor et al., in review). Hydrological studies of 62 climate change often address surface water, but fewer studies focus on groundwater 63 (Kundzewicz and Döll, 2009; Green et al., 2011). The predicted impacts of climate warming on 64 groundwater include changes in the magnitude and timing of recharge (e.g. Hiscock et al., 65 2012), typically with a shift in seasonal mean and annual groundwater levels depending on 66 changes in the distribution of rainfall (Liu, 2011) and snow melt (Jyrkama and Sykes, 2007;

67 Okkonen and Kløve, 2010). The predicted changes in recharge may be larger than the changes 68 in precipitation ( $\mathrm{Ng}$ et al., 2010). Land use and urbanisation may suppress or amplify 69 groundwater responses to climate change. For example, afforestation can increase recharge 70 (Chaves et al., 2012) and urbanisation can increase consumption (Taylor and Tindimugaya, 71 2012). In addition to human impacts, natural long-term fluctuations in groundwater levels 
72 caused by climate variability must be considered (Hanson et al., 2004; Gurdak et al., 2007;

73 Anderson and Emanuel, 2008).

74 Sustainable groundwater management in the future requires groundwater to be used in a manner

75 that can be maintained for an indefinite time without having unacceptable environmental, 76 economic or social consequences (Alley et al., 1999). Groundwater sustainability is a value-

77 driven process of intra- and inter-generational equity that balances the environment, society and 78 the economy (Gleeson et al., 2010, 2012). This requires groundwater management to be 79 approached in a holistic way, where all water uses are seen in the context of socio-economic 80 development and protection of ecosystems and ecosystem services (Constanza et al., 1997). The 81 current lack of knowledge on groundwater-ecosystem interactions can be seen as reflecting a

82 neglect of groundwater in integrated watershed management plans (UNEP/CBD, 2010). The

83 European Commission (EC) Groundwater Directive and Water Framework Directive raise 84 concerns about how groundwater use may affect ecosystems. Re-balancing of water allocation 85 between various human uses, as well as to biodiversity and ecosystem functioning, is clearly 86 needed (Showstack, 2004).

87

88 This paper focuses on groundwater and associated dependent aquatic and terrestrial ecosystems;

89 climate change effects on groundwater hydrology and geochemistry; and the processes affecting 90 global climate, which in turn influence hydrology, groundwater ecosystem interactions and 91 adaptation policies for groundwater and GDE management. The objective of the paper was to 92 synthesise current knowledge on the complex interactions between climate, groundwater and 93 ecosystems, and to examine integrated groundwater management strategies that account for 94 human and ecosystems needs. Although there are other recent reviews on climate change and 
groundwater (Earman and Dettinger, 2011; Green et al., 2011; Treidel et al., 2012; Taylor et al.,

96 in review), this is the first to synthesise the effects of climate change on GDE.

97

98

99

2. Review of climate change impacts on GDE

100

101

2.1 Climate change and climate variability

102 Climate change may be perceived as alterations in the local or global climate on different time 103 scales. Cyclical climate changes in a relative short time perspective are called climate 104 variability. For groundwater, this variability can be illustrated as oscillating changes in recharge 105 (P-ET), where the annual recharge varies in a regular or irregular manner that can resemble 106 oscillations (Fig. 1). Several natural phenomena related to atmospheric and (or) oceanic 107 circulation can affect the climate locally or globally, causing changes and (or) variability. Many 108 of these phenomena are related to the circulation of the oceans and (or) of the atmosphere. The 109 Gulf Stream, the North Atlantic Oscillation (NAO) and the El Niño-Southern Oscillation 110 (ENSO) are among the best known, but other phenomena such as the Pacific Decadal 111 Oscillation (PDO) and Atlantic Multidecadal Oscillation (AMO) have been described more 112 recently (e.g. Huss et al., 2010).

114 ENSO is the result of an interaction between the Pacific Ocean and the atmosphere whereby 115 anomalies in sea surface temperature (SST) co-vary with the intensity of the Southern 116 Oscillation (Rasmusson and Carpenter, 1982; McPhaden et al., 2006), while NAO is an 
117 atmospheric phenomenon centred over the North Atlantic (Hurrell et al., 2003). ENSO has a 118 typical quasi-periodic oscillation of 2-7 years, while NAO displays a yearly variability and a 119 decadal quasi-periodic oscillation. PDO has a 10-25 year quasi-periodic cycle that is associated 120 with decadal variability in atmospheric circulation prominent in the North Pacific, where 121 variations in the strength of the wintertime Aleutian Low pressure system co-vary with SST 122 from $20^{\circ} \mathrm{N}$ polewards (Mantua et al., 1997). AMO is an oceanic-atmospheric phenomenon with 123 a periodicity of 50-70 years that arises from variations in SST in the Atlantic Ocean (Kerr, 124 2000; Enfield et al., 2001). All these phenomena change the yearly climate regionally and 125 seasonally, so that some regions of the world become seasonally warmer or colder, or drier or 126 wetter, than normal. Associated with the effects of climate variability, oscillations in river 127 runoff have been extensively described in rivers worldwide (e.g. Cullen et al., 2002; Ionita et 128 al., 2012).

130 The effects of climate variability on groundwater have been less well explored than those on 131 surface water (Green et al., 2011). However, climate variability on interannual to multidecadal 132 time scales, including ENSO, NAO, PDO, and AMO, has also been shown to affect 133 groundwater levels and recharge (Hanson et al., 2004; Pool, 2005; Fleming and Quilty, 2007; 134 Gurdak et al., 2007, 2009; Anderson and Emanuel, 2008; Holman et al., 2009, 2011; Trembley 135 et al., 2011; Venencio and Garcia, 2011). It is likely that the signals seen in recharge are also 136 seen in groundwater levels, but as aquifers differ in size, the response to the input signal 137 variability will be more evident in smaller aquifers (Fig. 1). 
139 The increase in greenhouse gas emissions since the industrial revolution has also affected the

140 climate of the Earth. For example, a small but constant increase in mean atmospheric

141 temperature has been observed since then (IPCC, 2007). Human activities can also cause

142 climate change locally by changing land use, water use and vegetation, with consequent impacts

143 on hydrology (e.g. Collischon et al., 2001). These causes of climate change and variability are

144 continuously acting and interacting with each other. The result of such a complex system is that

145 in some periods their impacts are additive and enhance each other, while in other periods they

146 counteract each other and their impacts decline regionally (see Fig. 1).

147

148 Coupled global climate models (GCMs), which describe the circulation of the atmosphere and 149 the oceans, are frequently used to develop scenarios of future climate (rainfall, temperature, 150 radiation, etc.) taking into consideration different scenarios for increases in greenhouse gases. 151 Such scenarios include a constant increase in greenhouse gases for the next 100 years (scenario 152 A2 of IPCC) or a reduction in emissions (scenario B1 of IPCC), or anything in between. In any 153 case, future climate scenarios projected by GCMs in terms of precipitation and temperature may 154 be used to force hydrological models and numerical groundwater flow models in a sequential 155 (e.g. Okkonen and Kløve, 2011) or fully coupled manner (Therrien et al., 2007), in order to 156 predict the impacts of future climate on recharge, groundwater flow and interactions with 157 associated ecosystems. 
161 Climate change and variability have directly and indirectly affected, and will continue to affect, 162 groundwater quantity and quality in many complex and unprecedented ways (Holman, 2006;

163 Dettinger and Earman, 2007; Earman and Dettinger, 2011; Treidel et al., 2012; Taylor et al., in 164 review). Future climate change will affect recharge rates and, in turn, the depth of groundwater 165 levels and the amount of available groundwater (Ludwig and Moench, 2009). Much of the 166 research to date has focused on climate change effects on the magnitude and timing of recharge 167 (Döll, 2009; Green et al., 2011; Treidel et al., 2012), with less emphasis on whether recharge 168 mechanisms may change, possibly from more diffuse to focused recharge mechanisms in some 169 regions (Gurdak et al., 2007). Moreover, few papers have addressed how groundwater will be 170 indirectly affected by the changing patterns of groundwater abstraction and (or) land use 171 (Treidel et al., 2012). Increasing abstraction with reduced recharge can reduce groundwater 172 levels significantly, as demonstrated conceptually in Fig. 1. More studies have addressed the 173 potential effects of climate variability and change on recharge than natural or human-induced 174 changes in groundwater discharge. Furthermore, groundwater quality has received far less 175 attention than groundwater quantity (Treidel et al., 2012).

176 Groundwater recharge depends on the distribution, amount and timing of precipitation, 177 evapotranspiration losses, snow cover thickness and snow melt characteristics, and land use/land 178 cover. Warmer winter temperatures can reduced the amount of ground frost and allow more 179 water to infiltrate into the ground, resulting in increased groundwater recharge. The potential 180 recharge rate can increase by approximately $100 \mathrm{~mm} /$ year over a period of 40 years in Canada 181 (Jyrkama and Sykes 2007). Warmer winter shift the river peak flow earlier in a year resulting in 182 a similar shift in aquifer water levels (Scibek et al. 2007). Earlier snow melt can reduce summer 183 low flows (Okkonen and Kløve 2011). Summer low flows will also change due to melting and 
184 retreating glaciers; leading to first an increased summer flow as more ice is melted (Kumar and 185 Singh 1997), but eventually resulting in lower summer flow as glaciers retreat (Huss 2011). This 186 will influence glacier fed rivers such as Po that is linked to large confined aquifers and Glomma 187 which is linked to unconfined floodplain aquifers. Reduced river flow in dry periods will 188 influence the groundwater exchange directly and can also lead to more groundwater abstraction 189 as river water is less available. Lower groundwater tables can promote surface water recharge in 190 loosing streams as hydraulic gradients increase.

191 Recharge to an aquifer depends on the groundwater level, with lower positions normally 192 increasing the capture zone and recharge. The properties of the aquifer are also essential; small, 193 shallow unconfined aquifers respond more rapidly to climate change, whereas larger and 194 confined systems show a slower response. Unconfined aquifers, especially surficial and shallow 195 aquifers, are more likely to have renewable groundwater on meaningful time scales and will be 196 particularly sensitive to changes in variability and climatic conditions (Winter, 1999; Healy and 197 Cook, 2002; Sophocleous, 2002; Lee et al., 2006). Confined and deeper aquifers are more likely 198 to have non-renewable groundwater and will be less sensitive to the direct effects of climate 199 variability and change. Non-renewable groundwater is vulnerable to the indirect effects of 200 increased human abstraction to meet current water requirements (Wada et al., 2012) and future 201 water demand under a changing climate (Treidel et al., 2012).

202 Predicting spatiotemporal changes in the magnitude, timing and mechanism of recharge is 203 complex in most climate regions. For example, in semi-arid regions, only heavy rainfall events 204 result in groundwater recharge, whereas in humid regions an increase in heavy rainfall events 205 can reduce recharge rates because most water may be lost through runoff (Bates et al., 2008). 
206 In cold climates, seasonal variations in water level are common where a permanent snow cover

207 hinders groundwater recharge in winter, while snow melt water replenishes aquifers in spring

208 (Kuusisto, 1984; Rutulis, 1989; Van der Kamp and Maathuis, 1991). It is expected that in snow-

209 dominated regions, warmer winters will cause snow melt and groundwater recharge (e.g.

210 Jyrkama and Sykes, 2007; Sutinen et al., 2007) and runoff to occur over longer periods and

211 earlier in the year (e.g. Veijalainen et al., 2010). Increased aquifer recharge will increase

212 wintertime groundwater levels (see Mäkinen et al., 2008; Okkonen and Kløve, 2010), whereas

213 in spring and summer the groundwater levels may decrease with a warmer climate (Okkonen

214 and Kløve, 2010).

215 Some studies, for example that by Hiscock et al. (2012), have used GCMs to simulate future

216 precipitation and temperature trends based on a 'high' (SRES A1F1) gas emissions scenario by

217 the end of the $21^{\text {st }}$ century, and report that northern Europe will receive more winter rainfall,

218 leading to increased groundwater recharge but during a shorter time period, and that summers

219 will be drier, with longer periods of limited or no groundwater recharge. Dams et al. (2011)

220 showed for a catchment in Belgium that future climate change can reduce groundwater levels,

221 particularly in late summer-early autumn, and reduce groundwater discharge in regions with

222 little discharge. Southern Europe will have less recharge overall and the region may become

223 more water stressed than at present, with any increase in winter recharge unable to compensate

224 for the reduced autumn recharge (Hiscock et al., 2012). Southern Spain is predicted to be

225 among the worst affected regions in Europe, with almost total disappearance of recharge

226 (Hiscock et al., 2012).

227 Groundwater quality changes will be a consequence of changed recharge patterns and land-use.

228 Reduced soil frost result in more recharge and less overland flow (Okkonen and Kløve 2011). 
229 This can increases groundwater availability (Jyrkama and Sykes 2007) but also increase risk of 230 leaching of contaminants during winter (Okkonen et al. 2010). Warmer climate increase might 231 influence pesticide leaching to groundwater, but the processes are complex and mainly related 232 to land use changes driven by changes in climate (Bloomfield et al. 2007) and increased pest 233 pressures e.g. due to lower winter mortality (Noyes et al. 2006). In cold regions, a milder 234 climate with temperatures around freezing melting point increase the use of salt application for 235 slippery control (Balderacchi et al. 2013). In warmer climate, less recharge can lead to further 236 decline of groundwater levels. Reduced groundwater level increase the risk of contamination 237 mainly from sea water intrusion in coastal aquifers (Werner et al. 2013). Increased flood can 238 lead to river water being more polluted (e.g. Hrdinka et al. 2012) and reduced minimum flow 239 can lead to increase riverine concentration in wastewater effluents as waters are less diluted 240 posing a risk to groundwater in loosing streams with a direct contact to aquifers.

241 Changes to both groundwater and surface water levels may ultimately alter the interaction 242 between groundwater and surface water, as well as the interaction between natural and societal 243 water supply and demand (Hanson et al., 2012). Groundwater storage acts as a moderator of 244 surface water response and climate feedback (Maxwell and Kollet, 2008). For example, Hanson 245 et al. (2004) identified temporal changes in response to the low frequency variability of the 246 Pacific Decadal Oscillation (PDO) in groundwater-surface water interactions from a small 247 watershed in the south-western USA. Temporal changes in the PDO range of streamflow 248 (resulting from changes in precipitation and temperature due to PDO) at a downstream location 249 lagged behind those at an upstream location by about three-quarters of a year, which may 250 represent a delay in sustained downstream flows owing to streamflow infiltration to the 251 floodplain aquifer (Hanson et al., 2004). Changes in stream base flow and groundwater levels 
252 tended to precede changes in streamflow at some locations by about 1 or 2 years, which may 253 suggest that streamflow infiltration dominates prior to sustained streamflow during wet periods 254 (Hanson et al., 2004).

255 Climate-induced changes in groundwater/surface water interactions will directly affect wetlands 256 and other GDE (Earman and Dettinger, 2011; Kløve et al., 2012; Candela et al., 2012; 257 Tujchneider et al., 2012). It is likely that impacts on GDE will depend on changes in 258 groundwater and surface water levels and that they will vary depending on location in the 259 landscape and land use changes, as shown in Fig. 2. For local and intermediate scale systems 260 (Fig. 2), it likely that the spatial extension of GDE will diminish with decreasing groundwater 261 levels and surface water levels at increasing temperatures. Simulation results show that short262 flow-path groundwater systems, such as those providing baseflow to many headwater streams, 263 will likely have substantial changes in the timing of discharge in response changes in seasonality 264 of recharge; whereas regional-scale aquifer systems with flow paths on the order of many tens of 265 kilometers, in contrast, are much less affected by changes in seasonality of recharge (Waibel et 266 al. 2013). These effects are uncertain, however, and depend on local hydrogeology. More studies 267 should focus on changes in both groundwater and surface water, as well as their interactions with 268 climate change.

269 For terrestrial and riparian vegetation, a shift in location, as well as in species composition, can 270 occur. Changes in groundwater can change the wetland water balance, leading to lowered water 271 level and reduced groundwater inflow. For example, Candela et al. (2012) use downscaled 272 climate and groundwater model simulations to project a $17 \%$ reduction in recharge for the first 273 quarter of the $21^{\text {st }}$ century, most likely reducing groundwater discharge into wetlands of Majorca, 274 Spain. Ecosystems in coastal regions can be severely negatively affected by salt water intrusion 
275 at future higher sea water levels and reduced groundwater inflow (Fig. 2). Drexler et al. (2013)

276 observed a decrease of fen area of $10 \%$ to $16 \%$ from areal photos in Sierra Nevada due to

277 changes in groundwater inflow in 50-80 years. Losses of biodiversity in GDEs of Santa Fe

278 (Argentina) is related to decreasing discharge caused by increasing demand for groundwater and 279 decreasing recharge rates (Tujchneider et al., 2012). Treidel et al. (2012) suggest that the future 280 preservation of many wetlands and other GDE requires adaptive management actions that 281 decrease groundwater abstraction for irrigated agriculture and that re-locate wells with 282 detrimental effects on groundwater discharge to dependent ecosystems.

\subsection{Climate change in GDE}

285 To understand the impacts of climate change on ecosystems, we must understand all pressures 286 and their potential impacts in the ecosystem and their potential feedbacks. All external 287 pressures can change the ecosystem status, with changes typically becoming more severe with 288 increasing pressure (Fig. 3). The response will be scale-dependent, which is a source of 289 uncertainty as these responses are not well understood on smaller scales. Large-scale changes in 290 hydrology are not always seen at the aquifer scale, where the local hydrogeology is dominant 291 (Fig. 4). For groundwater systems, the natural variability in groundwater quantity and quality 292 will depend on the size of the capture zone and the scale of the groundwater system (Toth, 293 1963; Fig. 5A). From an ecological point of view, ecosystems fed by local groundwater systems 294 will show a more contrasted variation in temperature and nutrient concentrations than regional 295 capture zones (Bertrand et al., 2012; Fig. 5B). As a consequence, it is likely that larger systems 296 will be more resilient to climate change (Fig. 5C). In GDE, land use changes can alter abiotic 297 conditions, with potentially rapid responses in biological communities and processes. Land use 
298 changes may even override changes caused by large-scale changes in climate, as reflected in 299 regional hydrology (Fig. 4).

2.3.1 Climate change impacts in terrestrial ecosystems: Tree growth and distribution

302 Studies using GCMs indicate a warmer climate, with an increase in precipitation with increased $303 \mathrm{CO}_{2}$, for the $21^{\text {st }}$ century (Kundzewicz et al., 2007). Previous studies on the impacts of climate 304 change on terrestrial ecosystems focus on changes caused by predicted future changes in 305 precipitation, temperature and $\mathrm{CO}_{2}$ on evapotranspiration, growth (assimilation) and 306 distribution of vegetation, particularly young trees (Brolsma et al., 2010). The few modelling 307 studies done so far with fully coupled vegetation-hydrology models show complex interactions 308 and feedbacks from the combined effects of increased temperature, precipitation and $\mathrm{CO}_{2}$. 309 Increased $\mathrm{CO}_{2}$ reduces stomatal conductance, which reduces transpiration and counteracts a 310 potential increase in evapotranspiration caused by warming; Increased $\mathrm{CO}_{2}$ also increases 311 assimilation and plant growth, which results in higher biomass and transpiration. Increased 312 temperature could also lengthen the growing season, although the impact of daylight is 313 important (Saxe, 2001).

314 The main responses of GDE plants to modifications in groundwater resources and hydrology 315 can be summarised in a conceptual scheme (Fig. 6). At larger scales, a shift in zonation is 316 expected, with vegetation moving towards the poles and higher altitude. At the landscape scale, 317 drought- and wet-tolerant species will shift uphill and downslope (Brolsma and Birkens, 2007). 318 In the case of a general piezometric decrease, the effects on trees may be negligible or, 319 conversely, it may provoke a total extinction of the original ecosystem (Naumburg et al., 2005). 320 These effects depend on the interactions between biological (e.g. development or vegetative 
321 pause of the root system) and physical processes (soil water circulation, hydric potential

322 differences between roots and leaves) and tree adaptation abilities (root development rate). If

323 the tree cannot develop a deeper root system to keep in contact with the groundwater (rapid

324 lowering), this can be temporarily compensated for by soil moisture (e.g. Meinzer et al., 1999).

325 The resilience of ecosystems to resource abstraction is thus dependent on very local 326 meteorological conditions (meteorological water supply) and the yield capacity of the soil 327 layers (soil texture influencing soil water flow paths and accessibility to roots). In dry 328 conditions, rainfall frequency may decrease but average rainfall depth may increase, resulting in 329 increased recharge, which along with more deep-rooted vegetation can partly counterbalance 330 the impacts of climate change (Liu, 2011). Simulations for a temperate (wet climate) hillslope, 331 with reduced yearly rainfall and increased winter rainfall, show increased upslope recharge due 332 to decreased upslope biomass and increased winter rainfall, resulting in increased groundwater 333 levels and wetter conditions downslope and enlargement of wet-adapted vegetation cover 334 (Brolsma et al., 2010). However, the impacts of other growth-limiting factors such as nutrients, $335 \mathrm{pH}$, light and air humidity are not well known, rendering modelling results uncertain. For 336 example, vegetation disease is probably the most obvious consequence of groundwater 337 lowering (Scott et al., 1999). Water stress leads to reduced photosynthesis and transpiration, 338 stomata closure (Leffler et al., 2000; Sperry et al., 2002; Cooper et al., 2003) and sometimes to 339 xylem cavitation, especially in phreatophytes (Groeneveld et al., 1994). Xylem cavitation may 340 lead in turn to the death and disappearance of some branches, initially the most distal ones. In 341 snow and glacier-fed systems featuring high latitude and high altitude areas, a general 342 piezometric level increase may occur due to climate change (e.g. Beniston, 2006). In such 343 conditions, tree resiliency mostly depends on the capacity of the species to adapt to anoxic 
344 conditions. Even among phreatophytes, this capacity varies and is still difficult to evaluate

345 (Ganskopp, 1986; Groeneveld, 1990). In the case of prolonged anoxia, some trees may lose 346 their deepest roots and produce either shallower roots or roots adapted to anoxia (Groeneveld 347 and Crowley, 1988).

\subsubsection{Aquatic ecosystems: Lessons from surface waters}

350 Climate change is expected to impose environmental regimes that will exceed the resilience 351 capacity of most aquatic organisms (Poff et al., 2002). For example, shifts in the distributional 352 ranges of freshwater taxa will be equally obvious to, or may even exceed, those predicted for 353 most terrestrial organisms (Hickling et al., 2006). Given that inland waters are already among 354 the most heavily human-impacted environments, climate change represents an additional and 355 severe threat to freshwater ecosystems, altering their fundamental ecological processes and 356 species distributions (Poff et al., 2002; Woodward et al., 2010).

357 Water temperature is an important environmental variable in freshwater ecosystems that 358 directly influence organisms and ecosystem processes. Thermal regime regulates the growth 359 and development of aquatic organisms and therefore directly affects species distributions and 360 assemblage structure (Daufresne et al., 2004; Bertrand et al., 2012), as well as primary 361 production and organic matter decomposition (e.g. Richardson, 1992). Temperature in lakes 362 shows a correlation with air temperature and using this proxy Trumpickas et al. (2009) 363 predicted a considerable increase for lake temperature of the great lakes of USA. For rivers, the 364 increase in surface water temperature is mainly caused by reduced low flow and heat capacity 365 for as shown by modelling for the United States, Europe, eastern China, and parts of southern 366 Africa and Australia (Kane et al. 2013). Upto a $26 \%$ increase is expected for seasonal rivers 
367 due to changes in low flow (Kane et al. 2013). Air temperature fluctuations are seen to a depth 368 of 10-15 meters in groundwater, and a constant increase in soil mean temperature can be seen as 369 an increase in mean groundwater temperature upto $4{ }^{\circ} \mathrm{C}$ in temperate climate in simulations 370 using a considerable warming scenario (Taylor et al. 2009).

371 In addition to temperature, climate change also affects precipitation patterns and, consequently, 372 the hydrological regime, and these effects can sometimes be even more detrimental to 373 freshwater organisms than the direct effects of modified temperatures. Biota with low dispersal 374 abilities and long generation times (K-strategists according to Mac Arthur and Wilson, 2001) 375 are expected to be more common in permanently flowing springs, whereas biota with strong 376 dispersal ability (R-strategists) will be favoured in non-permanent discharge habitats (e.g. 377 Erman and Erman, 1995; Smith and Wood, 2002). Floods and droughts act as external 378 disturbances, causing displacement of organisms and their resources, while indirect effects of 379 discharge variation arise from interactions with the fluvial geomorphology and local stream 380 habitat structure (Poff et al., 1997). Site-specific conditions such as current velocity and 381 stability of sediments are likely to be modified by climatic-induced processes, which may alter 382 the species distribution (Bertrand et al., 2012). Furthermore, the effects of temperature and 383 discharge variability must be distinguished from land use-related environmental stressors such 384 as eutrophication, acidification and sedimentation (e.g. Evans, 2005). Thus far, only a few 385 attempts have been made to assess how changes in broad-scale climate factors will alter 386 hydrological regimes and how these interactions will affect biological communities (Daufresne 387 and Boët, 2007; Durance and Ormerod, 2007).

388 Freshwater springs are dependent on continuous discharge of groundwater and form subsurface389 surface water and aquatic-terrestrial ecotones, which are important components of riverine 
390 landscape biodiversity (Ward and Tockner, 2001). Springs and spring-fed streams are 391 considered physically stable environments that support stable biological communities (Barquin 392 and Death, 2006). Given that the thermal regime of groundwater systems is less dependent on 393 air temperature patterns than that of surface waters, the effects of altered air temperatures are 394 likely to be less pronounced in springs and other GDE. However, climate change-induced 395 modifications of recharge may have a profound impact on spring communities. Such changes 396 may by reflected in decreased groundwater level in summer, but increased winter level and 397 associated flooding can affect biological communities even more through changes in water 398 chemistry caused by intensified links between aquatic and terrestrial environments (Green et al., 399 2011). In addition to intensity, the timing of disturbance events may be critical for biological 400 communities. Freshwater organisms in boreal areas are evolutionarily adapted to a highly 401 predictable seasonal flow regime, and alteration of the hydrological regime to more 402 unpredictably occurring extreme flow events may result in serious problems for freshwater 403 biota. Spring organisms, however, are reported to have remarkable resilience to human-induced 404 disturbances. For example, Ilmonen et al. (2012) showed that invertebrate communities in 405 springs affected by forestry approximately 30 years prior to sampling did not differ appreciably 406 from those in non-modified reference springs.

3. Identification of research and data gaps

4103.1 Impact of climate change on the variability of groundwater quantity and quality 
411 For groundwater quantity, the fundamental issue is how recharge will be altered with climate 412 change. The response of plant transpiration to increased $\mathrm{CO}_{2}$, climate warming and changes in 413 soil moisture and groundwater elevation must be understood and included in recharge models. 414 More information is needed on groundwater recharge mechanisms, storage capacity and 415 residence times in cold and alpine conditions (Singleton and Moran, 2010; Treidel et al., 2012). 416 Most studies of climate change effects on surface hydrology in alpine, mountainous and snow417 dominated regions do not explore subsurface hydrological responses (Green et al., 2011). The 418 impacts of frost on soil hydraulic conductivity and recharge are large, but not fully understood 419 (Okkonen and Kløve, 2010). These mechanisms need to be included in numerical models. The 420 interactions between climate, groundwater and surface water must also be understood in order 421 to predict changes in groundwater recharge (Okkonen et al., 2010).

422 Only few studies have addressed the potential effects of climate change on groundwater quality 423 (Treidel et al., 2012). Even if climate change has no direct effect on local groundwater quality, 424 changes in the volume of groundwater entering GDE may change the quality of the receiving 425 waters (Earman and Dettinger, 2011). The limited number of studies conducted to date on 426 groundwater quality have primarily addressed seawater intrusion into coastal aquifers, and 427 some studies indicate that groundwater pumping is expected to have more of an effect than 428 climate change and sea level rise on seawater intrusion in some coastal aquifers (Treidel et al., 429 2012; Ferguson and Gleeson, 2012). However, the effect of climate change on air temperature 430 may influence groundwater temperatures and dissolved oxygen concentrations (Kløve et al., 431 2012; Haldorsen et al., 2012). This would have important implications for reaction rates and 432 reduction-oxidation (redox) reactions that directly affect the nitrogen and carbon cycle in soil 433 and groundwater, non-point source and point source contamination, and the fate of many 
434 groundwater contaminants. Climate-induced changes that alter biogeochemical processes may 435 make groundwater less suitable for drinking (Figura et al., 2011). The quality of groundwater 436 may be a limiting factor for some intended uses, such as drinking or irrigation, and for the long437 term sustainability of groundwater resources worldwide (Gurdak et al., 2012), and therefore 438 additional research is needed on regulation of groundwater quality. Changes in recharge rates 439 and mechanisms may also increase the mobilisation of pesticides and other pollutants in the 440 unsaturated zone and reduce groundwater quality (e.g. Gooddy et al., 2001; Johnson et al.,

441 2001; Bloomfield et al., 2006; Sugita and Nakane, 2007). In some semiarid and arid regions, 442 climate change may mobilise naturally occurring salts, such as nitrate and chloride porewater 443 reserves, or enhance denitrification and removal of nitrate from the unsaturated zone prior to 444 recharge (Gurdak et al., 2007). Stuart et al. (2011) noted that nitrate leaching to groundwater as 445 a result of climate change is not sufficiently well understood to make useful predictions without

446 additional monitoring data. Studies on natural soil and agricultural processes in the United 447 Kingdom report a range of nitrate leaching rates from a slight increase to possibly high nitrate 448 concentrations in groundwater by 2100 because of climate change (Stuart et al., 2011). In 449 addition, a possible increase in surface water intrusion and flooding poses a risk to groundwater 450 quality because of contamination by bacteria and organic matter from wetlands (Silander et al., 451 2006).

$453 \quad 3.2$ Impacts of climate change and groundwater change on ecosystems

454 Groundwater ecology as a scientific discipline is in its infancy (Larned 2012), and little is 455 known about how climate change will affect GDE and their biota. Considering the importance 456 of the ecosystem services provided by GDE to humankind, this lack of knowledge is 
457 unfortunate, as it hinders the adaptive management of GDE in the face of global environmental 458 change. Any management decisions need to deal with potential conflicts between human 459 resource use and GDE biodiversity. Many GDE support surprisingly high biodiversity and 460 levels of endemism (Boulton et al., 2008), thus being of considerable conservation value. 461 However, as they have suffered from human disturbance around the world, their unique biota is 462 rapidly becoming threatened (Heino et al., 2006; Barquín and Scarsbrook, 2008; Boulton, 463 2009).

464 Changes in groundwater input can influence water quality in ecosystems in several, partly 465 unknown, ways. A reduction in the average groundwater level tends to enhance soil aeration 466 and thus organic matter oxidation. This can lead to nutritive enrichment, mostly through 467 production of $\mathrm{NO}_{3}{ }^{-}$and $\mathrm{PO}_{4}{ }^{3-}$, which are generally the limiting nutrients in GDE (Wassen et al., 468 2005). In aerobic conditions, $\mathrm{PO}_{4}{ }^{3-}$ may become toxic due to its fixation with the oxidised form 469 of iron $\left(\mathrm{Fe}^{3+}\right)$ in the root zone (Boomer and Bedford, 2008). An increase in groundwater flux 470 may result in waterlogged conditions, anoxic processes and associated fluxes of contaminants 471 (Werner and Zedler, 2002; Olde Venterink et al., 2006). This may unbalance the nutritive 472 equilibrium through the production of reduced species such as $\mathrm{Fe}^{2}+$ (which might also release $473 \mathrm{PO}_{4}^{3-}$ bound to $\mathrm{Fe}^{3+}$ ), $\mathrm{Mn}^{2+}$ (important nutrient but often at toxic concentrations in acid soils; 474 El-Jaloual and Cox, 1998), or $\mathrm{N}_{2}$ (which can only be taken up by roots in symbiosis with 475 particular nitrogen-fixing bacteria).

476 If rainfall increases, acidification of the superficial zones of ecosystems may occur (Wassen et 477 al., 1996; Grootjans et al., 2006; Bertrand et al., 2008). This process should be perceptible after 478 several years of hydrological modifications (van Diggelen et al., 1996; van der Hoek and 479 Sýkora, 2006; van Belle et al., 2006). Furthermore, acidification rate depends on organic acid 
480 production in situ (Kooijman and Paulissen, 2006), sulphur dynamics (Devito and Hill, 1997),

481 and the acid-buffering ability of soils (van Bremen and Buurman, 2002).

482 Secondary hydrological changes in GDE due to altered water balance and groundwater levels 483 have so far received little attention in climate change studies. The generation and maintenance 484 of peat soils over time depend on hydrological conditions, and in recent studies of peatlands 485 exposed to groundwater lowering, soil cracking, peat subsidence and secondary changes in 486 water flow and storage patterns have been observed (Kværner and Snilsberg, 2008, 2011).

\subsection{Impact of land use and water management}

489 Groundwater is necessary for many human and natural systems and is a substantial economic 490 resource in most developed and developing countries (Hiscock et al., 2012). The management of 491 groundwater resources has many policy implications outside the immediate water sector 492 (Ludwig and Moench, 2009). These include implications for agriculture and food security, 493 energy, human health and safety (White and Falkland, 2012), and the conservation of 494 groundwater-dependent ecosystems (Chaves et al., 2012; Kløve et al., 2012). Many policy and 495 management decisions directly affect groundwater and (or) climate, which in turn further 496 modifies groundwater resources. Examples of such policies are self-sufficency policy leading 497 which in arid regions leads to cultivation of crops with high water requirement instead of crops 498 with less water needs (Khalid 2013). In cold climate, agriculture is supported with European 499 Union subsidence despite surface and groundwater being vulnerable due to high runoff and 500 pristine water quality of that are easily contaminated. Also bioenergy crops expansion to 501 marginal agricultural soils leads more pollution. Thus, policy decisions must carefully assess 
502 implications to the climate-water-society complex and the sustainability of groundwater 503 resources (Treidel et al., 2012).

504 While most studies have addressed the response of recharge and groundwater/surface water 505 interactions to climate change, quantifying groundwater withdrawals and use remains a difficult 506 but necessary challenge (Treidel et al., 2012). Groundwater withdrawals for drinking water, 507 agriculture and industry have a major effect on most groundwater resources and are a 508 component of the groundwater budget that can be controlled directly by adaptive management 509 practices and policy decisions. Treidel et al. (2012) conclude that additional scientific studies are 510 needed in most aquifers of the world to quantify spatial and temporal patterns of groundwater 511 discharge, withdrawals and uses in response to present and future climate.

514 The quantification of climate change impacts on groundwater systems and GDE can be 515 explored by running groundwater models with future meteorological boundary conditions, 516 which may be derived from future climate scenarios computed with climate models. However, 517 there is a vast range of different GCMs with differing assumptions on ocean-atmosphere 518 interaction, initial conditions and emission scenarios. Some of the GCMs are dynamically 519 refined to regional climate models (RCMs). For various regions in particular, the predictions on 520 changes in precipitation differ between different climate models. Furthermore, a statistical bias 521 correction is sometimes performed based on station data (Themeß1 et al., 2011), which draws on 522 the idea that a good fit on historical data proves the adequacy of the climate model for 523 prediction of future climate changes. However, this involves the assumption of stationarity and, 524 in addition, it is questionable whether available data records are long enough to reliably 
525 represent natural climate variability and anthropogenically induced climate change (Kiem and 526 Verdon-Kidd, 2011).

527 Typically, the spatial discretisation of climate models is in the order of tens of square 528 kilometres. Thus, climate model results cannot reflect processes on a smaller spatial scale, 529 which is particularly problematic in regions with strongly varying topography. Moreover, an 530 aquifer or even more a GDE and its catchment might be of substantially smaller proportions. As 531 input for hydrological models, time series of temperature and precipitation measurements are 532 needed at the very least. While the resulting temperature data might be in line with observed 533 data, this is rarely the case for precipitation. Seasonal patterns or shorter wet or dry periods are 534 often poorly predicted in climate model outputs. This reduces the applicability of predicted 535 precipitation time series for hydrological impact studies.

536 One way to get around this is the Delta approach, where a factor is added to observed 537 meteorological variables to mimic the future time series affected by change (Taylor and 538 Tindimugaya, 2012). This change factor can be derived from climate model outputs or can 539 include stochastic or soft paleoclimatic components to account for climate variability 540 components not included in observations. Goderniaux et al. (2011) describe an approach where 541 they combine the change factor with a transient stochastic weather generator to address the 542 uncertainty from different model structures and parameterisations in driving GCMs and RCMs.

543 Hydrological models run for climate change impact studies should be integrated with 544 simultaneous consideration of processes in the unsaturated and saturated zones, overland and 545 channel flow, soil-atmosphere interactions and, when relevant, the effects of snow and frozen 546 soil. In general, climate change impacts on groundwater systems and GDEs are indirect 547 consequences of changes in precipitation, evapotranspiration and surface runoff. Groundwater 
548 systems then face altered patterns and magnitudes of recharge from water that has moved 549 through the unsaturated zone and/or surface water levels that lead to different exchange 550 conditions. Depending on the focus of a study, emphasis can be placed on modelling sub551 processes and treating the other water balance components as boundary conditions with or 552 without feedback. Thus, a decision has to be made on the level of hydrological model 553 complexity justified given the existing hydrological data for model calibration.

554 To model climate change impacts on GDE, hydraulic aspects (e.g. extent of capture zone or 555 critical groundwater level conditions) need to be complemented by data on biological and 556 geochemical processes. For example, groundwater temperature is an important driver of all 557 biological activities, which in turn might influence water quality in multiple ways. Thus, 558 modelling processes within GDEs may become highly nonlinear. Finally, future scenarios also 559 need to include transient assumptions about land use change, socioeconomic developments and, 560 in particular, water abstraction, as these affect groundwater systems and thus GDE.

561 Overall, a consistent strategy has to be developed to link relevant GDE processes to the 562 surrounding groundwater system, considering strongly diverging temporal and spatial 563 application scales. One crucial component is to disentangle the sequence of nonlinear feedbacks 564 between hydraulic and biological processes. Moreover, the prospects for numerical modelling 565 of the most relevant GDE problems need to be clearly identified and further described. If 566 numerical models are to be used as a tool to provide the link between climate change impacts 567 on GDE, a number of challenges must be met in a consistent manner. In this context, the 568 propagation of uncertainty from the climate model outputs through hydrological models must 569 be taken into account. 
$571 \quad$ 4. New approaches

572

5734.1 Integrated multidisciplinary monitoring of groundwater and GDE and new methods in the 574 field of ecohydrology

575 In the future, groundwater systems and use of these resources need to be studied in a 576 multidisciplinary way in order to better understand the interaction between processes on the soil 577 surface related to hydrology and land use, and the relationship between groundwater and 578 ecosystems. Modelling is needed to link the complex natural processes to groundwater 579 extraction, land use and management effects. For such integrated studies, data are required on 580 land use changes and water extraction, groundwater-dependent ecosystems, and groundwater581 surface water interactions. We also need to understand how ecosystems depend on hydrological 582 drivers and how they respond to predicted changes in hydrology (Fig. 4, 6). Monitoring data 583 should include information on geomorphology, ecology and hydrology. Such data are usually 584 unavailable in national monitoring efforts, which generally focus on groundwater levels or river 585 discharges. Smaller-scale monitoring is needed for systems relevant for future ecosystem 586 protection and legislation (e.g. NATURA 2000 ecosystems).

587 Several new methods could be introduced in GDE research. Plant responses to water stress 588 could be followed on short and longer time scales (Table 1) to verify the predicted changes in 589 plants. As ecosystem responses will vary spatially, the monitoring networks need to be spatially 590 distributed within a catchment. In many cases groundwater flowpaths are not well known, and 591 tracer methodologies could be used to obtain this information. New tracers such as Nobel gases 592 are also available for assessing changes in climate. It will be important to carry out climate 593 change assessments that consider all reasons for climate change, including climate variability 
and the impact of urbanisation on climate. For this, long series of records are crucial, as climate 595 (and recharge) can oscillate with wavelengths of more than 50 years. However, many long-term 596 weather monitoring stations are affected by the urban heat island effect (Hamdi, 2010) and 597 temperature data must be used with care.

\subsection{Modelling as a future management tool}

600

Given the numerous challenges in combining climate model results and groundwater and GDE

601 model applications, and the varying importance of different processes in different and complex

602 GW-GDE systems, a promising approach is to use elaborated conceptual models to pinpoint the 603 most important steps and drivers and set up a problem-specific model chain. Alternatively, the

604 fully integrated hydrological modelling approach can be pursued (e.g. Goderniaux et al., 2011), 605 but this requires either powerful computers (due to long CPU response times) or modelling 606 compromises within the spatial model resolution.

607 The conceptual model/model chain procedure may involve establishment of a list of indicators 608 that describe GDE vulnerability, followed by identification of the linkages between these 609 indicators and climate change-related impacts. The latter aspects should also include different 610 levels of model proficiency, e.g. numerical modelling of water temperature is understood quite 611 well, whereas other (in particular GDE-related) processes and their temporal and spatial 612 variations are currently less well described.

613 Furthermore, the role of the unsaturated zone in transferring climate change signals to 614 groundwater systems and GDE needs to be better clarified (Treidel et al., 2012). Goderniaux et 615 al. (2011) state that the unsaturated zone smooths groundwater recharge flux variations so that 
616 groundwater levels become insensitive to seasonal fluctuations in the weather, but rather reflect

617 multiannual fluctuations. However, $\mathrm{Ng}$ et al. (2010) found that changes in average precipitation 618 are amplified by changes in average recharge, leading to nonlinearities due to the temporal 619 distribution of precipitation change.

620 Uncertainty in hydrological modelling should not be overlooked, although it has been shown to

621 be smaller than that in climate modelling. It is dependent on the kind of hydrological system 622 investigated and the specific hydrological models used. Along that line, Ng et al. (2010) present 623 a combined probabilistic approach that explicitly accounts for uncertainties in meteorological 624 forcing by applying a stochastic weather generator and soil and vegetation properties by 625 generating realisations that are conditioned on soil moisture and soil water chloride 626 observations.

629 Indicators are widely seen as a means of bridging the gap between scientific research and 630 political needs. Political organisations often recommend the development of indicators and 631 teams of experts and academics carry out this task (Hinkel, 2011). Indicators represent a tool for 632 ecological assessment, while indices (e.g. multimetric indices, composite indices) are highly 633 integrative, allowing broad-scale questions to be addressed using a few carefully selected 634 parameters (Innis et al., 2000). The use of indicators requires a comprehensive understanding of 635 the structural components of an ecosystem and the interactions between, and responses to, 636 various stresses of these components, as well as their spatial and temporal variability. Rigorous 637 testing and validation are necessary to establish such an understanding (Innis et al., 2000). 638 Although the messages of different indicators are complex, careful assessment may allow 
639 policy makers to identify aspects and stressors of ecosystems requiring improvements of 640 existing policies.

641 Despite financial and operational constraints, there is a need for monitoring and evaluation of 642 groundwater status. To this end, chemical and sometimes microbial indicators have been 643 analysed in many GDE. For example, groundwater pollution due to agricultural activities is 644 shown by $\mathrm{NO}_{3}-\mathrm{N}$ and $\mathrm{PO}_{4}-\mathrm{P}$ content, which may result in failure to comply with national and 645 EU water quality regulations. Heavy metals and metalloids, as well as hydrocarbons and 646 pesticides, must meet the standard values, being generally under the detection limits (Cruz et 647 al., 2009).

648 Groundwater has been selected as one of the terrestrial Essential Climatic Variables (ECVs) by 649 GTOS (Global Terrestrial Observation System). Several critical variables have been considered 650 under the heading "groundwater": groundwater level, groundwater recharge and discharge, and 651 water quality. Of these, groundwater level is a direct indicator of groundwater supply and 652 withdrawal rates, while the GTOS Panel on Climate recognises that groundwater discharge and 653 recharge are critical indicators of climate change. Despite the priority given to chemical status, 654 biological, physical and radiological factors are also considered when assessing groundwater 655 quality.

656 Current indicator systems (e.g. groundwater indicators or water quality indicators according to 657 the EC Water Framework Directive, WFD) need to be strengthened and applied more 658 consistently and universally. However, much more remains to be done to produce or to 659 aggregate indicators relevant to assessing the vulnerability of GDE. All existing indices of 660 vulnerability to climate change show substantial conceptual, methodological and empirical 661 weaknesses, including lack of focus, lack of a sound conceptual framework, methodological 
662 flaws, high sensitivity to alternative methods for data aggregation and limited data availability 663 (Füssel, 2009).

664 A common approach to GDE assessment requires scientific consensus. Improvements in data 665 availability can be realised through better organisation and interoperability of databases. Many 666 indicators have been developed under national and EU programmes (in projects providing 667 scientific support for WFD or GWD implementation in different EU countries), but have not 668 reached their potential.

669 The selection of elements in an indicator set is critical. An appropriate indicator must

670 incorporate several spatial and temporal scales and multiple environmental factors (physical, 671 chemical and biotic) to provide robust results. The use of carefully selected indicators 672 maximises the amount and quality of information about the ecological integrity of a system, 673 while minimising the time and expense involved.

674 Whether, and which, indicators are useful for vulnerability assessment or climate change 675 adaptation policy remains an open question. Before this question can be addressed, goals and 676 targets of specific indicators in climate-relevant policy fields need to be evaluated and refined 677 frequently (Hinkel, 2011).

678

\section{4.4 Integrated management of groundwater and GDE}

680 The accelerating trend for withdrawal and use of groundwater over recent decades has been 681 essential in the development of many regions of the world, producing large social and economic 682 benefits through the provision of low-cost, drought-reliable and high-quality water supplies. 683 Many regions have large groundwater-dependent economies. This fast expansion has been 
684 referred to as the "silent revolution", in the sense that in many regions it has followed a bottom-

685 up approach, driven by the personal initiative of millions of individual farmers in pursuit of the 686 significant short-term benefits usually provided by groundwater (Llamas and Martinez-Santos, 687 2005). Such developments are often uncontrolled and not incorporated into a comprehensive 688 land and water management plan at the basin scale, resulting in overexploitation and 689 groundwater degradation and drainage impacts on GDE.

690 Sustainable development of groundwater is a major challenge that is expected to be exacerbated 691 by the potential impact of climate change. The expected increase in the frequency and intensity 692 of dry periods might lead to increased and unsustainable abstraction of groundwater resources 693 (Green et al., 2011). Groundwater is bound to play a decisive role in adapting water resource 694 management to climate change. Forward planning for adaptation of groundwater management 695 to global (climate and land-use) change is essential in order to develop sustainable practices to 696 cope with the impacts of future climate change. This adaptation should consider the local 697 context, the dominant drivers and their projected impact on groundwater resources in the future 698 (World Bank, 2009).

699 Integrated Water Resources Management (IWRM) requires the coordinated development of 700 water, land and related resources in order to maximise the resultant economic and social welfare 701 in an equitable manner, without compromising the sustainability of vital ecosystems (GWP, 702 2000). Groundwater management within the general IWRM framework requires integration of 703 an appropriate policy and regulatory framework, institutional arrangements, social participation 704 and economic instruments to be fully effective (Foster and Ait-Kadi, 2012). In future IWRM, 705 GDE have to be seen as an integral part of groundwater resources. 
706 Some of the challenges for the adaptation of integrated groundwater management to climate 707 change are:

- Appropriate institutional/regulatory framework for groundwater appropriation and use. Groundwater management is best carried out through the collaborative efforts of a regulatory agency and aquifer management organisation involving representatives of local associations of water users and other stakeholder groups (Garduno and Foster 2010). The decisive role of collective action in groundwater governance is being increasingly recognised (Lopez-Gunn, 2003; Lopez-Gunn and Martinez-Cortina, 2006).

- Economic management instruments. Groundwater and GDE services are often undervalued (economic externalities and groundwater economic value are scarcely recognised), which has often led to inefficient patterns of groundwater use, resulting in overexploitation and pollution problems. With increasing water scarcity, the economic value of groundwater is rising. It is essential to study the total economic value of the resource in order to assess the net benefits of management actions (NRC, 1997). There is an array of economic instruments that can provide the appropriate incentives for efficient groundwater extraction and management. Although the economic instruments to manage surface water and groundwater are similar, they are not identical due to certain special characteristics associated with groundwater, including the relatively high cost and complexity of assessing groundwater, the highly decentralised nature of resource use and the high monitoring costs, and the long time-lags and near irreversibility of most aquifer contamination. The selection and use of a particular economic instrument will depend on hydrological, economic, social and political considerations. Abstraction charges provide direct incentives for water saving. There are 
two alternatives: pricing through resource abstraction fees or indirect pricing through increasing energy tariffs. Water markets have been advocated to improve resource management, especially with regard to more efficient water use and allocation within and between sectors. Groundwater banks also offer new perspectives for water management in drought conditions (Howitt, 2004; Pulido-Velazquez et al., 2004).

- Integrated conjunctive management of surface and groundwater and GDE. Conjunctive use $(\mathrm{CU})$ is the coordinated management of surface and groundwater resources, taking advantage of their complementary properties. Jointly operating all manageable water resources in a river basin or region can increase the yield, efficiency, supply reliability and cost-effectiveness of a system. CU not only refers to artificial recharge practices, but to a broad range of options (including alternating use of surface water and groundwater, managed stream/aquifer interaction, etc.) which can occur in different temporal patterns and within active or passive management, according to the region's development status and planning objectives (Pulido-Velazquez et al., 2003; Sahuquillo and Lluria, 2003). Tanaka et al. (2006) used a state-wide hydroeconomic optimisation model to analyse water supply in California under climate change scenarios for the year 2100. They found that the system can adapt to significant changes in climate and land use through major changes in the operation of the large groundwater storage capacity and conjunctive use management, significant transfers of water among users (water markets) and the adoption of new technologies.

- Land use regulations to protect groundwater resources and GDE. Management of groundwater quality requires the protection of aquifers and groundwater from ingress of pollutants and also the remediation/treatment of polluted resources. However, treatment 
of polluted groundwater is complex, expensive and often only partially successful, and it

753

754

755

756

757

758

759

760

761

762

763

764

765

7665 Conclusions

767 Climate processes influence groundwater patterns in a complex way, with a number of direct 768 and indirect effects. Future recharge can reflect normal climate variability, human-induced 769 warming and local land and water management. These changes may counteract or amplify each 770 other. The influence of past climate must be studied over a long time scale (e.g. 70-100 years) to 771 reveal natural variability.

772 Climatic variables influence hydrological processes, so any change in precipitation, 773 evapotranspiration, snow accumulation and snow melt will influence recharge and groundwater 
774 formation. It is not fully understood how evapotranspiration changes with increased 775 temperature, $\mathrm{CO}_{2}$ and alterations in rainfall patterns. In cold climates, the response in terms of 776 snow melt, frost and winter hydrology and recharge needs to be better quantified. Changes in 777 groundwater interaction with surface water are important for groundwater recharge and must be 778 better understood. Studies on groundwater are needed from regions with different socio779 economic development, land uses and hydrogeological settings.

780 Climate model outputs have been used to assess changes in hydrology. So far these climate 781 models do not estimate changes in climate at a scale useful for studies of changes in small 782 groundwater deposits and in GDE. Future scenarios of precipitation, wind speed and radiation 783 are all highly uncertain compared with the predicted changes in temperature. Changes in land 784 use patterns, irrigation, vegetation cover and water use are not well understood and 785 documented. The present state of climate response modelling must therefore include a proper 786 assessment of uncertainties in input variables and predicted changes in water consumption and 787 land use. As drought is a major threat to GDE, it is important that impact studies include an 788 assessment of drought on the water supply. Typically, drought effects can be seen only after 789 several years of drought, when groundwater levels are lowered.

790 The impacts on ecosystems will vary depending on the type of ecosystem, amount of water 791 input and changes in water input. For some groundwater systems, the changes in temperature 792 may be smaller than for surface waters. The expected change will depend on the existing 793 quantitative and qualitative stresses on these ecosystems. Conceptual and numerical models can 794 be useful for predicting future changes in ecosystems, but the effect response in these systems is 795 not well known. Many processes are highly non-linear and should be included in numerical 796 models. In major aquifers used for drinking water production, data on groundwater levels are 
797 available, but for smaller systems information is scarce. In most cases, monitoring on 798 ecosystem scale is lacking in national monitoring programmes. Generalising the effects on 799 groundwater quantity and quality for any particular region is challenging and subject to 800 considerable uncertainty.

801 Groundwater is important for both economies and ecosystems. In future, groundwater should be 802 managed in a multidisciplinary way in order to provide efficient solutions. Numerical models 803 will be essential for understanding the complex interactions in GDE, while simple indicators 804 will be helpful for monitoring the results of policy practices in GDE. As the study of GDE is 805 new, more research and development is needed. This should include the development of 806 scientific methodologies and national monitoring activities.

808 Acknowledgements

809 The preparation of this review was partly funded by EC $7^{\text {th }}$ framework project GENESIS 810 (contract number 226536).

\section{References}

814 Alley, W.M., Reilly, T.E., Franke, O.L. 1999. Sustainability of ground-water resources. US

$815 \quad$ GeolSurvCirc 1186, 79 pp

816 Anderson Jr., W.P., Emanuel, R.E. 2008. Effect of interannual and interdecadal climate 817 oscillations on groundwater in North Carolina. Geophysical Research Letters, v. 35, L23402, doi:10.1029/2008GL036054. 
Balderacchi, M., Benoit, P.; Cambier, P.; Eklo, O.M.; Gargini, A.; Gemitzi, A.; Gurel, M.; Kløve, B.; Nakic, Z.; Preda, E.; Ruzicic, S.; Wachniew, P.; Trevisan, M. 2013. Groundwater pollution and quality monitoring approaches at the European level. Critcal Reviews of Environmental Science and Technology 43:323-408.

Barquin, J. and Death, R.G. 2006. Spatial patterns of diversity in New Zealand springs and rhithral streams. Journal of the North American Benthological Society 25: 768-786.

Barquín, J. and Scarsbrook, M. 2008. Management and conservation strategies for coldwater springs. Aquatic Conservation: Marine and Freshwater Ecosystems 18: 580-591.

Bates, B., Kundzewicz, Z.W., Wu, S., Palutikof, J.P. 2008. Climate change and water. Technical paper vi of the Intergovernmental Panel on Climate Change. Intergovernmental Panel on Climate Change Secretariat, Geneva, 210 pp.

Beniston, M. 2006. Mountain weather and climate: A general overview and a focus on climatic change in the Alps. Hydrobiologia 562, 3-16.

Bertrand G., Celle-Jeanton H., Laj P., Rangognio J., Chazot G., 2008. Rainfall chemistry: long range transport versus below cloud scavenging. A two-year study at an inland station (Opme, France). Journal of Atmospheric Chemistry 60 (3), 253-271

Bertrand, G., Goldscheider, N., Gobat, J.M., Hunkeler, D. 2012. Review: from multi-scale conceptualization of groundwater-dependent ecosystems to a classification system for management purposes. Hydrogeology Journal 20, 5-25.

Bloomfield, J.P., Williams, R.J., Gooddy, D.C., Cape, J.N., Guha, P. 2006. Impacts of climate change on the fate and behaviour of pesticides in surface and groundwater - a UK perspective. Sci Total Environ 369, 163-77. 
841 Boomer, K.M.B., Bedford, B.L. 2008. Groundwater-induced redox-gradients control soil 842 properties and phosphorus availability across four headwater wetlands, New York, USA. Biogeochemistry 90, 259-274.

Boulton, A.J. 2009. Recent progress in the conservation of groundwaters and their dependent ecosystems. Aquatic Conservation Marine and Freshwater Ecosystems 19: 731-735.

Boulton, A.J., Fenwick, G.D., Hancock, P.J., Harvey, M.S. 2008. Biodiversity, functional roles and ecosystem services of groundwater invertebrates. Invertebrate Systematics 22: 103116.

Bradley, D.C., Ormerod, S.J. 2001. Community persistence among stream invertebrates tracks the North Atlantic Oscillation. Journal of Animal Ecology 70: 987-996.

Brolsma, R.J., van Vliet, M.T.H., Bierkens, M.F.P. 2010, Climate change impact on a groundwater-influenced hillslope ecosystem, Water Resour. Res., 46, W11503, doi:10.1029/2009WR008782.

Brolsma, R.J., Bierkens, M.F.P. 2007. Groundwater-soil water-vegetation dynamics in a temperate forest ecosystem along a slope, Water Resour. Res., 43, W01414, doi:10.1029/2005WR004696.

Candela, L., Von Igel, W., Elorza, F. J., Aronica, G., 2009. Impact assessment of combined climate and management scenarios on groundwater resources and associated wetland (Majorca, Spain). J. Hydrol. 376, 510-527.

Candela, L., von Igel, W., Elorza, F.J., Jimenez-Martinez, J. 2012, Impact assessment of combined climate and management scenarios on groundwater resources, pp. 191-204. In Treidel, H., Martin-Bordes, J.J. and Gurdak, J.J. (Eds.). Climate Change Effects on Groundwater Resources: A Global Synthesis of Findings and Recommendations. 
International Association of Hydrogeologists (IAH) - International Contributions to

865

866

867

868

869

870

871

872

873

874

875

876

877

878

879

880

881

882

883

884 Hydrogeology, Taylor \& Francis publishing, 414 p.

Chaves, H.M.L., Camelo, A.P.S., Mendes, R.M. 2012. Groundwater discharge as affected by land-use change in small catchments: A hydrologic and economic case study in central Brazil, pp. 49-62. In Treidel, H., Martin-Bordes, J.J. and Gurdak, J.J. (Eds.). Climate Change Effects on Groundwater Resources: A Global Synthesis of Findings and Recommendations. International Association of Hydrogeologists (IAH) - International Contributions to Hydrogeology, Taylor \& Francis publishing, 414 p.

Collischonn, W., Tucci, C.E.M., Clarke, R.T. 2001 Further evidence of changes in the hydrological regime of the River Paraguay: part of a wider phenomenon of climate change? Journal of Hydrology 245, 218-238.

Costanza, R., d'Arge, R, de Groot, R.S. et al., 1997. The total value of the world's ecosystem services and natural capital. Nature 387: 253-260.

Cooper, D.J., D’Amico, D.R., Scott, M.L. 2003. Physiological and morphological response patterns of Populusdeltoides to alluvial ground water pumping. Environmental Management31, 215-226

Cruz, J.V., Pacheco, D., Cymbron, R. 2009. Monitoring of the groundwater chemical status in the Azores archipelago (Portugal) in the context of the EU water framework directive, Environ Earth Sci. DOI 10.1007/s12665-009-0334-8

Cullen, H.M., Kaplan, A., Arkin, P.A., Demenocal, P.B. 2002. Impact of the North Atlantic Oscillation on Middle Eastern climate and streamflow. Climatic Change 55, 3, 315-338. 
900

901

902

Dams, J., Salvadore, E., Van Daele, T., Ntegeka, V., Willems, P., Batelaan, O. 2011. Spatiotemporal impact of climate change on the groundwater system.Hydrol. Earth Syst. Sci. Discuss., 8, 10195-10223.

Daufresne, M., Boët, P. 2007. Climate change impacts on structure and diversity of fish communities in rivers. Global Change Biology 13: 1-12.

Daufresne, M., Roger, M.C., Capra, H. Laramoux, N. 2004. Long-term changes within the invertebrate and fish communities of the Upper Rhône River: effects of climatic factors. Global Change Biology 10: 124-140.

Dettinger, M.D., Earman, S., 2007. Western ground water and climate change - pivotal to supply sustainability or vulnerable in its own right? Ground Water 4(1), 4-5.

Devito, K.J., Hill, A.R., 1997. Sulphate dynamics in relation to groundwater-surface water interactions in headwater wetlands of the southern Canadian Shield. Hydrological Processes 11, 485-5000.Drexler, J. Z. Knifong, D. Tuil, J. Flint, L. E. Flint, A. L. 2013. Fens as whole-ecosystem gauges of groundwater recharge under climate change, Journal of Hydrology 481 (25), 22-34.

Döll, P., 2009. Vulnerability to the impact of climate change on renewable groundwater resources: a global-scale assessment. Environ. Res. Lett. 4 (3), 035006.

Durance, I., Ormerod, S.J. 2007. Climate change effects on upland stream macroinvertebrates over 25-year period. Global Change Biology 13: 942-957.

Earman, S., Dettinger, M. 2011, Potential impacts of climate change on groundwater resources - a global review. J. Water Climate Change 2(4), 213-229.

El-Jaloual T., Cox, D.A., 1998. Manganese toxicity in plants. Journal of Plant Nutrition 21, 353386. 
Enfield, D.B., Mestas-Nunez, A.M., Trimble, P.J. 2001. The Atlantic Multidecadal Oscillation and its relationship to rainfall and river flows in the continental U.S., Geophys. Res. Lett., 28, 2077-2080.

Erman, N.A., Erman, D.C. 1995. Spring permanence, Trichoptera species richness, and the role of drought. J Kansas Entomol Soc 68(2):50-64

Evans, C.D. 2005. Modelling the effects of climate change on an acidic upland stream. Biogeochemistry 74: 21-46.

Ferguson, G., Gleeson, T. 2012. Vulnerability of coastal aquifers to groundwater use and climate change. Nature Climate Change, doi:10.1038/NCLIMATE1413.

Figura, S., Livingstone, D.M., Hoehn, E., and Kipfer, R. (2011) Regime shift in groundwater temperature triggered by the Arctic Oscillation: Geophysical Research Letters 38, L23401, doi:10.1029/2011GL049749, p. 1-5.

Fleming, S.W., Quilty, E.J. 2007. Aquifer Responses to El Nino-Southern Oscillation, Southwest British Columbia. Ground Water 44(4), doi: 10.1111/j.1745-6584.2006.00187.x, 595-599.

Foster, S., Ait-Kadi, M., 2012. Integrated Water Resources Management (IWRM): How does groundwater fit in? Hydrogeology Journal 20(3), 415-418.

Füssel, H.-M. 2009. Review and quantitative analysis of indices of climate change exposure, adaptive capacity, sensitivity, and impacts. Background note to the World Development Report 2010

Garduno, H., Foster, S. 2010. Sustainable groundwater irrigation-approaches to reconciling demand with resources. GW-MATE Strategic Overview Series 4, World Bank, Washington, DC. www.worldbank.org/gwmate 
931 Ganskopp, D.C. 1986. Tolerance of sagebrush, rabbitbrush, and greasewood to elevated water tables. Journal of Range Management 39, 334-337.

Gleeson, T., VanderSteen, J., Sophocleous, M.A., Taniguchi, M., Alley, W.M., Allen, D.M., Zhou, Y. 2010. Groundwater sustainability strategies. Nature Geosciences 3(6), 378-379. VanderSteen, J. 2012. Towards sustainable groundwater use: Setting long-term goals, backcasting, and managing adaptively. Ground Water 50(1), 19-26.

Goderniaux, P., Brouyere, S., Blenkinsop, S., Burton, A., Fowler, H.J., Orban, P., Dassargues, 939 A. 2011. Modeling climate change impacts on groundwater resources using transient stochastic climate scenarios. Water Resours. Res., 47, W12516, doi:10.1029/2010WRR010082.

Gonzalez Bernaldez, F., Rey Benayas, J.M., Martinez, A. 1993. Typology of impacts produced by groundwater extraction. Journal of Hydrology 141(1-4), 219-238

Gooddy, D.C., Bloomfield, J.P., Chilton, P.J., Johnson, A.C., Williams, R.J. 2001. Assessing herbicide concentrations in the saturated and the unsaturated zone of a chalk aquifer in southern England. Ground Water 39(2):262-271

Green, T.R., Taniguchi, M., Kooi, H., Gurdak, J.J., Allen, D.M., Hiscock, K.M., Treidel, H., Aureli, A. 2011. Beneath the surface: impacts of climate change on groundwater. Journal of Hydrology 405: 532-560.

Groeneveld, D.P. 1990. Shrub rooting and water acquisition on threatened shallow groundwater habitats in the Owens Valley, California. In McArthur, E. D., E. M. Romney, S. D. Smith, and P. T. Tueller (eds.), Proceedings_-Symposium on cheatgrass invasion, shrub die-off, 
and other aspects of shrub biology and management. USDA Forest Service GTR INT-276, $221-237$.

Groeneveld, D.P., Warren, D.C., Hubbard, P.J. 1994. Responses of five dominant Owens Valley scrub phreatophytes to controlled water table drawdown. County of Inyo and City of Los Angeles Technical Group, Los Angeles, 72 p.

Groeneveld, D.P., Crowley, D.E., 1988. Root system response to flooding in three desert shrub species. Functional Ecology 2, 491-497.

Grootjans, A.P., Adema, E.B., Bleuten, W., Joosten, H., Madaras, M., Janáková, M. 2006.

Hydrological landscape settings of base-rich fen mires and fen meadows: an overview. Appl. Veg. Sci. 9, 175-184.

Gurdak, J.J., Hanson, R.T., Green, T.R. 2009. Effects of climate variability and change on groundwater resources of the United States, U.S. Geological Survey Fact Sheet 20093074, 4 p., http://pubs.usgs.gov/fs/2009/3074/.

Gurdak, J.J., Hanson, R.T., McMahon, P.B., Bruce, B.W., McCray, J.E., Thyne, G.D., Reedy, R.C. 2007. Climate variability controls on unsaturated water and chemical movement, High Plains aquifer, USA. Vadose Zone J. 6 (3), 533-547.

Gurdak, J.J., McMahon, P.B., Bruce, B.W. 2012. Vulnerability of groundwater quality to human activity and climate change and variability, High Plains aquifer, USA, pp. 145-167. In Treidel, H., Martin-Bordes, J.J., and Gurdak, J.J., (Eds.). Climate Change Effects on Groundwater Resources: A Global Synthesis of Findings and Recommendations. International Association of Hydrogeologists (IAH) - International Contributions to Hydrogeology, Taylor \& Francis publishing, 414 p. 
975 GWP. 2000. Integrated Water Resources Management (IWRM). Stockholm: Global Water 976 Partnership.

977 978

979 980 981 982 983 984 985 986 987 988 989 990 991 992 993

Haldorsen, S., Heim, M., van der Ploeg, M. 2012. Impacts of climate change on groundwater in permafrost areas - case study from Svalbard, Norway, pp. 323-340. In Treidel, H., MartinBordes, J.J., and Gurdak, J.J., (Eds.). Climate Change Effects on Groundwater Resources: A Global Synthesis of Findings and Recommendations. International Association of Hydrogeologists (IAH) - International Contributions to Hydrogeology, Taylor \& Francis publishing, $414 \mathrm{p}$

Hamdi, R. 2010. Estimating urban heat island effects on the temperature series of Uccle (Brussels, Belgium) using remote sensing data and a land surface scheme. Remote Sensing 2(12): 2773-2784.

Hanson, R.T., Flint, L.E., Flint, A.L., Dettinger, M.D., Faunt, C.C., Cayan, D., Schmid, W. 2012. A method for physically based model analysis of conjunctive use in response to potential climate changes, Water Resour. Res., 48, W00L08, doi:10.1029/2011WR010774.

Hanson, R.T., Newhouse, M.W., Dettinger, M.D. 2004. A methodology to assess relations between climatic variability and variations in hydrologic time series in the southwestern United States. J. Hydrology 287(1-4), 252-269.

Healy, R.W., Cook, P.G. 2002. Using groundwater levels to estimate recharge. Hydrogeology Journal 10: 91-109.

Heino, J., Virtanen, R., Vuori, K.-M., Saastamoinen, J., Ohtonen, A., Muotka, T. 2006. Spring bryophytes in forested landscapes: land use effects on bryophyte species richness, community structure and persistence. Biological Conservation 124: 539-545. 
Hickling, 2006, R., Boy, D.B., Hill, J.K., Fox, R., Thomas, C.D. 2006. The distributions of a wide range of taxonomic groups are expanding polewards. Global Change Biology 12: 450-455.

Hinkel, J. 2011. Indicators of vulnerability and adaptive capacity: Towards a clarification of the science-policy interface, Global Environmental Change 21:198-208

Hiscock, K., Sparkes, R., Hodgens, A. 2012, Evaluation of future climate change impacts on European groundwater resources, pp. 351-366. In Treidel, H., Martin-Bordes, J.J., and Gurdak, J.J., (Eds.). Climate Change Effects on Groundwater Resources: A Global Synthesis of Findings and Recommendations. International Association of Hydrogeologists (IAH) - International Contributions to Hydrogeology, Taylor \& Francis publishing, $414 \mathrm{p}$

Holman, I.P. 2006.Climate change impacts on groundwater recharge-uncertainty, shortcomings, and the way forward? Hydrogeol J 14:637-647.

Holman, I.P., Rivas-Casado, M., Howden, N.J.K., Bloomfield, J.P., Williams, A.T. 2009. Linking North Atlantic ocean-atmosphere teleconnection patterns and hydrogeological responses in temperate groundwater systems. Hydrol.Proc. 23, 3123-3126.

Holman, I.P., Rivas-Casado, M., Bloomfield, J.P., Gurdak J.J. 2011.Identifying non-stationary groundwater level response to North Atlantic ocean-atmosphere teleconnection patterns using wavelet coherence.Hydrogeol J, doi:10.1007/s10040-011-0755-9.

Howitt, R. 2004. Empirical analysis of water market institutions: The 1991 California water market. Resource and Energy Economics, 16(4), 357-371. on water quality, Journal of Hydro-environment Research, 6 (2), 145-150. 
1020 Hurrell, J.W., Kushnir, Y., Ottersen, G., Visbeck, M. (Eds.) 2003. The North Atlantic 1021 Oscillation: Climatic Significance and Environmental Impact, Geophys. Monogr. Ser., vol. 134, 279 pp., AGU, Washington, D. C., doi:10.1029/GM134.

1023

1024

1025

1026

1027

1028

1029

1030

1031

1032

1033

1034

1035

1036

1037

1038

1039

1040

1041

1042

1043

Huss, M., Hock, R., Bauder, A., Funk. M. 2010. 100-year mass changes in the Swiss Alps linked to the Atlantic Multidecadal Oscillation, Geophys. Res. Lett., 37, L10501, doi:10.1029/2010GL042616.

Ilmonen, J. Virtanen, R., Paasivirta, L., Muotka, T. 2012. Responses of spring macroinvertebrate communities to habitat modification: community composition, specie richness and redlisted species. Freshwater Science (in press).

Innis, S., Naiman, R., Elliott, S.R. 2000. Indicators and assessment methods for measuring the ecological integrity of semi-aquatic terrestrial environments. Hydrobiologia 422/423: 111131

Ionita, M. Lohmann, G. Rimbu, N. Chelcea, S. 2012. Interannual variability of Rhine River streamflow and its relationship with large-scale anomaly patterns in spring and autumn. Journal of Hydrometeorology 13, 1, 172-188.

IPCC 2007. Contribution of Working Groups I, II and III to the Fourth Assessment Report of the Intergovernmental Panel on Climate Change. Core Writing Team, Pachauri, R.K. and Reisinger, A. (Eds.) IPCC, Geneva, Switzerland. pp 104.

Johnson A.C., Besien T.J., Bhardwaj C.L., Dixon A., Gooddy D.C., Haria A.H., White C. 2001. Penetration of herbicides to groundwater in an unconfined chalk aquifer following normal soil applications. Journal of Contaminant Hydrology 53(1-2):101-117.

Jyrkama, I.M., Sykes, J.F. 2007. The impact of climate change on spatially varying groundwater recharge in the grand river watershed. Journal of Hydrology 338(3-4):237-250Kane, E. S . Chivers, M.R.. Turetsky, M.R Treat, C.C. Petersen, D.G. Waldrop, M. 
Harden, J.W. McGuire, A.D. 2013. Response of anaerobic carbon cycling to water table manipulation in an Alaskan rich fen, Soil Biology and Biochemistry 58, 50-60.

Kerr, R.A. 2000. A north Atlantic climate pacemaker for the centuries, Science, 288, 1984-1985, doi:10.1126/science.288.5473.1984.

Kiem, A.S., Verdon-Kidd, D.C. 2011. Steps toward "useful" hydroclimatic scenarios for water resource management in the Murray-Darling Basin, Water Resour. Res., 47, W00G06, doi:10.1029/2010WR009803.

Kløve, B., Ala-aho, P., Okkonen, J., Rossi, P. 2012. Possible effects of climate change on hydrogeological systems: results from research on esker aquifers in northern Finland, pp. 305-322. In Treidel, H., Martin-Bordes, J.J., and Gurdak, J.J., (Eds.). Climate Change Effects on Groundwater Resources: A Global Synthesis of Findings and Recommendations. International Association of Hydrogeologists (IAH) - International Contributions to Hydrogeology, Taylor \& Francis publishing, 414 pp.

Kløve, B., Ala-aho, P., Bertrand, G., Boukalova, Z., Ertürk, A., Goldscheider, N., Ilmonen, J., Karakaya, N., Kupfersberger, H., Kværner J., Lundberg A., Mileusnić M., Moszczynska A., Muotka T., Preda E., Rossi P., Siergieiev D., Šimek J., Wachniew P., Widerlund A. 2011a. Groundwater dependent ecosystems: Part I - Hydroecology, threats and status of ecosystems. Environmental Science and Policy 14, 770-781.

Kløve, B., Ala-aho, P., Allan, A., Bertrand, G., Druzynska, E., Ertürk, A., Goldscheider, N., Henry, S., Karakaya, N., Karjalainen, T.P., Koundouri, P., Kværner, J., Lundberg, A., Muotka, T., Preda, E., Pulido Velázquez, M., Schipper, P. 2011b. Groundwater dependent 
ecosystems: Part II - Ecosystem services and management under risk of climate change and land-use management. Environmental Science and Policy 14, 782-793.

Konikow, L., Kendy, E. 2005. Groundwater depletion: A global problem. Hydrogeol J 13:317320, doi: 10.1007/s10040-004-0411-8

Kooijman, A.M., Paulissen, M.P.C.P. 2006. Higher acidification rates in fens with phosphorus enrichment. Appl. Veg. Sci. 9, 205-212.

Kundzewicz, Z.W., Mata, L.J., Arnell, N.W., Doll, P., Kabat, P., Jimenez, B., Miller, K.A., Oki, T., Sen, Z., Shiklomanov, I.A. 2007. Freshwater resources and their management. In Parry, M.L., Canziani, O.F., Palutikof, J.P., van der Linden, P.J., Hanson, C.E. (Eds.), Climate Change 2007: Impacts, Adaptation and Vulnerability. Cambridge University Press, Cambridge, pp. 173.

Kundzewicz, Z. W. \& Döll, P. (2009) Will groundwater ease freshwater stress under climate change? Hydrol. Sci. J. 54(4), 665-675.

Kuusisto, E. 1984. Snow accumulation and snow melt in Finland. Helsinki Finland, National Board of Waters, Publications of the Water Research Institute 55.

Kværner, J., Snilsberg, P. 2008. Romeriksporten railway tunnel — Drainage effects on peatlands in the Lake Northern Puttjern area. Engineering Geology 101, 75-88

Kværner, J., Snilsberg, P. 2011. Groundwater hydrology of boreal peatlands above a bedrock tunnel - Drainage impacts and surface water groundwater interactions. Journal of Hydrology 403, 278-291.

Larned, S. 2012. Phreatic groundwater ecosystems: research frontiers in freshwater ecology. Freshwater Biology (in press). 
1089 Lee, L.J.E., Lawrence, D.S.L., Price, M. 2006. Analysis of water level response to rainfall and 1090 implications for recharge pathways in the Chalk aquifer, SE England. Journal of Hydrology 1091 330: 604-620.

1092 Leffler, A.J., England, L.E., Naito, J. 2000.Vulnerability of Fremont cottonwood (Populus 1093 fremontii Wats.) individuals to xylem cavitation. Western North American Naturalist 60, $1094 \quad 204-210$.

1095 Liu, H.H. 2011. Impact of climate change on groundwater recharge in dry areas: An 1096 ecohydrology approach. Journal of Hydrology 407, 175-183

1097 Llamas, M.R., Martínez-Santos, P. 2005. Intensive groundwater use: silent revolution and 1098 1099 potential source of social conflicts. Journal of Water Resources Planning and Management, 131(5), 337-341

Lopez-Gunn, E. 2003..The role of collective action in water governance: a comparative study of groundwater user associations in La Mancha aquifers (Spain). Water International 28(3), $367-378$.

Lopez-Gunn, E., Martinez-Cortina, L. 2006. Is self-regulation a myth? Case study on Spanish groundwater associations and the role of higher level authorities. Hydrogeology Journal 14 (3); March, 361-375.

Ludwig F., Moench, M. 2009. The impacts of climate change on water. In Ludwig F., Kabat, P., Schaik, H.V., and van der Valk, M. (eds.) Climate change Adaptation in the Water Sector.

1109 Mac Arthur, R.H., Wilson, E.O. 2001. The Theory of Island Biography. Princeton Landmarks in 1110 Biology edn., Princeton University Press, Princeton, NJ, 203 pp 
1111 Mantua, N. J., Hare, S.R., Zhang, Y., Wallace, J.M., Francis, R.C. 1997. A Pacific interdecadal

1112

1113

1114

1115

1116

1117

1118

1119

1120

1121

1122

1123

1124

1125

1126

1127

1128

1129

1130

1131

1132

1133

climate oscillation with impacts on salmon production, Bull. Am. Meteorol. Soc., 78(6), 1069-1080.

Mäkinen, R., Orvomaa, M., Veijalainen, N., Huttunen, I. 2008. The climate change and groundwater regimes in Finland. Proceedings 11th International Specialized Conference on Watershed \& River Basin Management, Budapest, Hungary.

Maxwell, R.M., Kollet, S.J. 2008, Interdependence of groundwater dynamics and land-energy feedbacks under climate change: Nature Geoscience, v. 1, doi: 10.1038/ngeo315, p. 665669.

McPhaden, M.J., Zebiak, S.E., Glantz, M.H. 2006. ENSO as an integrating concept in earth science. Science New Series 314(5806), 1740-1745.

Meinzer F.C., Andrade, J.L., Goldstein, G., Holbrook, N.M., Cavelier, J., Wright, S.J. 1999. Partitioning of soil water among canopy trees in a seasonally dry tropical forest. Oecologia $121,293-301$.

Naumburg, E., Mata-Gonzalez, R., Hunter, R., McLendon, T., Martin, D.W. 2005. Phreatophytic vegetation and groundwater fluctuations: A review of current research and application of ecosystem response modelling with an emphasis on Great Basin vegetation. Environmental Management 35, 726-740.

Ng, G.-H.C., McLaughlin, D., Entekhabi, D., Scanlon, B.R. 2010. Probabilistic analysis of the effects of climate change on groundwater recharge, Water Resour. Res., 46(7), W07502, doi:10.1029/2009WR007904.

NRC. 1997. Valuing Ground Water: Economic Concepts and Approaches. National Research Council. Washington, DC: The National Academies Press. 
1134 Noyes, P. D. McElwee, M. K. Miller, H. D. Clark, B. W. Van Tiem, L. A. Walcott, K. C. 1135 Erwin, K. N. Levin, E. D. 2009. The toxicology of climate change: Environmental contaminants in a warming world, Environment International 35 ( 6), 971-986.

Okkonen, J. Jyrkama, M. Kløve, B. 2010. A climate change assessment framework for ground water. Hydrogeology journal 18 (2), 429-439.

1139

1140

1141

1142

1143

1144

1145

1146

1147

1148

1149

1150

1151

1152

1153

1154

1155

1156
Okkonen, J., Kløve, B. 2010. A conceptual and statistical approach for the analysis of climate impact on ground water table fluctuation patterns in cold conditions. Journal of Hydrology $388(1-2), 1-12$.

Okkonen, J., Jyrkama, M., Kløve, B. 2010. A climate change assessment framework for ground water. Hydrogeology Journal 18 (2), 429-439.

Okkonen, J., Kløve, B. 2011. A sequential modelling approach to assess groundwater-surface water resources in a snow dominated region of Finland. Journal of Hydrology 441 (1-2), 91-107.

Olde Venterink, H., Vermaat, J.E., Pronk, M., Wiegman, F., van der Lee, G.E.M., van den Hoorn, M.W., Higler, M.L.W.G., Verhoeven, J.T.A. 2006. Importance of sediment deposition and denitrification for nutrient retention in floodplain wetlands. Appl. Veg. Sci. 9:163-174

Poff, N.L., Allan, J.D., Brain, M.B., Karr, J.R., Prestegaard, K.L., Richter, D., Sparks, R.E., Stromberg, J.C. 1997. The natural flow regime. Bioscience 47: 769-784.

Poff, N.L., Brinson, M.M., Day, J.W. 2002. Aquatic Ecosystems and Global Climate Change. Potential Impacts on Inland Freshwater and Coastal Wetland Ecosystems in United States. Pew Center on Global Climate Change, Arlington. htpp://www.pewclimate.org/doc Uploads/ aquatic.pdf. 
1157 Pool, D.R., 2005. Variations in climate and ephemeral channel recharge in southeastern

1158

1159

1160

1161

1162

1163

1164

1165

1166

1167

1168

1169

1170

1171

1172

1173

1174

1175

1176

1177

1178

1179

Arizona, United States. Water Resources Research 41, W11403, doi:10.1029/2004WR003255.

Pulido-Velázquez, M., Marques, G.F. Jenkins, M.W., Lund, J.R. 2003. Conjunctive use of ground and surface water: classical approaches and California examples. Proceedings of the XI World Water Congress, CEDEX, Ministerio de MedioAmbiente. Madrid (Spain).

Pulido-Velazquez, M., Jenkins, M.W., Lund, J.R. 2004. Economics values for conjunctive use and water banking in Southern California. Water Resour. Res., 40(3), W03401.

Rasmusson, E.M., Carpenter, T.H. 1982. Variations in tropical sea surface temperature and surface wind fields associated with the Southern Oscillation/El Niño. Monthly Weather Review, 110, 354-384.

Richardson, J.H. 1992. Coarse particulate detritus dynamics in small montane streams of the south western British Columbia. Canadian Journal of Fisheries and Aquatic Sciences 49: $337-346$.

Rutulis, M. 1989. Groundwater drought sensitivity of southern Manitoba. Canadian Water Resources Journal 4: 18-33.

Sahuquillo, A., Lluria M. 2003, Conjunctive use as potential for stressed aquifers: social constraints. In R. Llamas and E. Custodio (eds), Intensive Use of Groundwater: Challenges and Opportunities, Balkema, Abingdon, Exton and Tokyo

Saxe, H., M. G. R. Cannell, B. Johnsen, M. G. Ryan, and G. Vourlitis (2001), Tree and forest functioning in response to global warming, New Phytol., 149(3), 369-399.

Scibek, J. Allen, D. M. Cannon, A. J. Whitfield, P. H.2007. Groundwatersurface water interaction under scenarios of climate change using a high- 
1182 Scott, M.L., Shafroth, P.B., Auble, G.T. 1999. Responses of riparian cottonwoods to alluvial water table declines. Environmental Management 23, 347-358.

Showstack, R. 2004. Discussion of challenges facing water management in the 21st century. Eos Trans. AGU, 85(6), 58, doi:10.1029/2004EO060002.

Silander J., B.Vehviläinen, J. Niemi, A. Arosilta, T. Dubrovin, J. Jormola, V. Keskisarja, A. Keto, A. Lepistö, R. Mäkinen, M. Ollila, H. Pajula, H. Pitkänen, I. Sammalkorpi, M.

Sophocleous, M. 2002. Interaction between groundwater and surface water: the state of the

Singleton, M.J., Moran, J.E. 2010. Dissolved noble gas and isotopic tracers reveal vulnerability Mimeographs 336, Helsinki. of groundwater in a small, high elevation catchment to predicted climate change. Water Resour Res 46: W00F06. doi:10.1029/2009WR008718

Smith, H., Wood, P.J. 2002. Flow permanence and macroinvertebrate community variability in limestone spring systems. Hydrobiologia 487:45-58

1203 Sugita, F., Nakane, K. 2007. Combined effects of rainfall patterns and porous media properties 
on nitrate leaching. Vadose Zone J 6, 548-53.

1205 Sutinen, R., Hänninen, P., Venäläinen, A. 2007. Effect of mild winter events on soil water 1206 content beneath snowpack. Cold regions science and technology. DOI:10.1016/2007.05.014.

1208 1209

1210

1211

1212

1213

1214

1215

1216

1217

1218

1219

1220

1221

1222

1223

1224

1225

Tanaka, S.K., Zhu, T., Lund, J.R., Howitt, R.E., Jenkins, M.W., Pulido-Velázquez, M., Tauber, M., Ritzema, R.S., Ferreira, I.C. 2006. Climate warming and water management adaptation for California. Climatic Change, 76 (3-4), 361-384.Taylor, C. A. Stefan, H. G. 2009. Shallow groundwater temperature response to climate change and urbanization, Journal of Hydrology, 375 (3-4) 601-612.

Taylor, R.G., Scanlon, B., Döll, P., Rodell, M., van Beek, R., Wada, Y., Longuevergne, L., Leblanc, M., Famiglietti, J.S., Edmunds, M., Konikow, L., Green T.R., Chen, J., Taniguchi, M., Bierkens, M.F.P., MacDonald, A., Fan, Y., Maxwell, R.M., Yechieli, Y., Gurdak, J.J., Allen, D., Shamsudduha, M., Hiscock, K., Yeh, P.J.F., Holman, I., Treidel, H. Groundwater and climate change. Nature Climate Change (in review).

Taylor, R., Tindimugaya, C. 2012. The impact of climate change and rapid development on weathered crystalline rock aquifer systems in the humid tropics of sub-Saharan Africa: evidence from south-western Uganda, pp. 17-32. In Treidel, H., Martin-Bordes, J.J., and Gurdak, J.J., (Eds.). Climate Change Effects on Groundwater Resources: A Global Synthesis of Findings and Recommendations. International Association of Hydrogeologists (IAH) - International Contributions to Hydrogeology, Taylor \& Francis publishing, $414 \mathrm{pp}$ 
1226

1227

1228

1229

1230

1231

1232

1233

1234

1235

1236

1237

1238

1239

1240

1241

1242

1243

1244

1245

1246

1247
Themeß1, M., Gobiet, A., Leuprecht, A. 2011. Empirical-statistical downscaling and error correction of daily precipitation from regional climate models, Int. J. Climatol., 31, 15301544, doi:10.1002/joc. 2168 .

Therrien, R., McLaren, R.G., Sudicky, E.A., Panday, S.M. 2007. HydroGeoSphere - A three dimensional numerical model describing fully-integrated subsurface and surface flow and solute transport. Users's Guide. Canada, Universite' Laval and University of Waterloo.

Toth, J. 1963. A theoretical analysis of groundwater flow in small drainage basins. J Geophys Res 68(16),4785-4812

Treidel, H., Martin-Bordes, J.J., Gurdak, J.J. (Eds.) 2012. Climate Change Effects on Groundwater Resources: A Global Synthesis of Findings and Recommendations. International Association of Hydrogeologists (IAH) - International Contributions to Hydrogeology, Taylor \& Francis publishing, 414 p.

Tremblay, A., Larocque, M., Anctil, F., Rivard, C. 2011. Teleconnections and interannual variability in Canadian groundwater levels: Journal of Hydrology 410, doi:10.1016/j.jhydrol.2011.09.013, p. 178-188.Trumpickas, J. Shuter, B. J. Minns, C. K. 2009. Forecasting impacts of climate change on Great Lakes surface water temperatures, Journal of Great Lakes Research 35 (3), 454-463.

Tujchneider, O., Paris, M., Perez, M., D’Elia, M. 2012, Possible effects of climate change on groundwater resources in the central region of Santa Fe Province, Argentina, pp. 265-280. In Treidel, H., Martin-Bordes, J.J., and Gurdak, J.J., (Eds.). Climate Change Effects on Groundwater Resources: A Global Synthesis of Findings and Recommendations. 

Hydrogeology, Taylor \& Francis publishing, 414 p.

UNEP/CBD (United Nations Environment Programme/Convention of Biological Diversity) 2010. In depth review of the program of the work on the biological diversity of inland water ecosystems. Prepared for $14^{\text {th }}$ meeting, Nairobi, 10-12 May 2010.

van Belle, J., Barendregt, A., Schot, P., Wassen, M.J. 2006. The effects of groundwater discharge, mowing and eutrophication on fen vegetation evaluated over half a century. Appl. Veg. Sci. 9, 195-204.

van Bremen, N., Buurman P. 2002. Soil Formation.2nd ed. Kluwer Acad. Publishers, Dordrecht, NL.

Van der Kamp G., Maathuis, H. 1991. Annual fluctuations of groundwater levels as a result of loading by surface moisture. Journal of Hydrology 127: 137-152.

van der Hoek D., Sýkora K.V. 2006. Fen-meadow succession in relation to spatial and temporal differences in hydrological and soil conditions. Appl. Veg. Sci. 9, 185-194.

van Diggelen, R., Molenaar, W.J., Kooijman, A.M.. 1996. Vegetation succession in a floating mire in relation to management and hydrology. J. Veg. Sci. 7, 809-820.

Veijalainen, N., Lotsari, E., Alho, B., Vehviläinen, B., Käyhkö, J. 2010. National scale assessment of climate change impacts on flooding in Finland. Journal of Hydrology 391: $333-350$.

Venencio, M.D.V., Garcia, N.O. 2011. Interannual variability and predictability of water table levels at Santa Fe Province (Argentina) within the climatic change context. Journal of Hydrology 409, doi:10.1016/j.jhydrol.2011.07.039, p. 62-70. 
1270 Wada, Y., van Beek, L.P.H., van Kempen, C.M., Reckman, J.W.T.M., Vasak, S., Bierkens

1271

1272

1273

1274

1275

1276

1277

1278

1279

1280

1281

1282

1283

1284

1285

1286

1287

1288

1289

1290

1291

1292

M.F.P. 2010. Global depletion of groundwater resources. Geophys. Res. Lett. 37, L20402, doi:10.1029/2010GL044571.

Wada, Y., van Beek, L.P.H., Bierkens, M.F.P. 2012. Nonsustainable groundwater sustaining irrigation: A global assessment, Water Resources Research 48, doi:10.1029/2011WR010562.

Waibel, M.S. Gannett, M.W. Chang, H. Hulbe, C.L. 2013. Spatial variability of the response to climate change in regional groundwater systems - Examples from simulations in the Deschutes Basin, Oregon, Journal of Hydrology 486 (12),187-201.

Ward, J.V., Tockner, K. 2001. Biodiversity: towards a unifying theme for river ecology. Freshwater Biology 46: 807-819.

Wassen, M.J., van Diggelen, R., Wolejko, L., Verhoeven, J.T.A. 1996. A comparison of fens in natural and artificial landscapes. Vegetatio 126, 5-26.

Wassen, M. J., H. G. M. Olde Venterink, E. D. Lapshina, and F. Tanneberger. 2005. Endangered plants persist under phosphorus limitation. Nature 437:547-550.

Werner, A. D. Vincent M. B. Post, E.A. Vandenbohede, . Lu, C. Ataie-Ashtiani, B. Simmons, C. T. Barry, D.A. 2013. Seawater intrusion processes, investigation and management: Recent advances and future challenges, Advances in Water Resources 51, 3-26.

Werner, K.J., Zedler, J.B. 2002. How sedge meadow soils, microtopography, and vegetation respond to sedimentation. Wetlands 22:451-466

White, I., Falkland, T. 2012. Reducing groundwater vulnerability in carbonate island countries in the Pacific, pp. 75-112. In Treidel, H., Martin-Bordes, J.J., and Gurdak, J.J., (Eds.). Climate Change Effects on Groundwater Resources: A Global Synthesis of Findings and 
1293 Recommendations. International Association of Hydrogeologists (IAH) - International 1294 Contributions to Hydrogeology, Taylor \& Francis Publishing, 414 p

1295 Woodward, G., Perkins, D. M., Brown, L.E. 2010. Climate change and freshwater ecosystems:

1296 Impacts across multiple levels of organization. Phil. Trans. R. Soc. B 365, 2093-2106.

1297 World Bank. 2009. Water and climate change: Impacts on groundwater resources and adaptation 1298 options. Water Unit, - Energy, Transport, and Water Department.

1299

1300

1301

1302 